CESIS Electronic Working Paper Series

Paper No. 205

\title{
Are Services Different Exporters?
}

\author{
Hans Lööf \\ CESIS, KTH
}

December 2009 


\title{
Are Services Different Exporters?
}

\author{
Hans Lööf
}

First version Dec 2009, revised version Feb 2010

\begin{abstract}
Using an unbalanced panel of about 260,000 Swedish firm-level observations over the period 1997-2006, this paper shows that half of the firms exporting goods are service firms that account for a substantial and increasing share of the total value from exports of goods. Between 1997 and 2006 this fraction increased from 25\% to 34\%. Previous research provides little systematic evidence of this extension of goods exports among service firms or the benefits of exporting. This paper shows that service firms do become exporters for the same reasons as manufacturing firms. Besides, they are a self-selection of larger, more productive and high-equity firms, with more skilled labour, higher capital intensity and stronger links to multinational groups. However, the export productivity premium is larger for service firms than for manufacturers. No evidence is found to indicate that exporting increases the growth rate of productivity. In contrast, the annual employment growth premium from exporting is substantial for business services, $2 \%$ per year, compared to $0.5 \%$ for the retail and wholesale business. Employment growth among manufacturing firms also benefits from expanded market opportunities in foreign markets.
\end{abstract}

Keywords: export productivity premium, manufacturing, services, micro data, panel data.

JEL:

C16, F14, L25, O33

${ }^{*}$ Centre of Excellence for Science and Innovation Studies, Royal Institute of Technology, Stockholm. Email: hans.loof@abe.kth.se 


\section{Introduction}

In their seminal paper, Bernard and Jensen (1999) listed a number of stylized facts on manufacturing exporters: exporters are better than non-exporters and exporters are larger, more productive, more capital-intensive and pay higher wages. Influenced by Bernard and Jensen (1999), a surge of studies have tried to determine whether goods firms become exporters (self-selection) or whether exporting improves the performance (learning by exporting).

In contrast to the growing body of analyses of exporting firms, studies of services operating in foreign markets are still very limited. The main reason is lack of data. Very few countries are systematically recording exports from services at the firm level, and typically the only data available is on goods export by services.

This paper uses data on goods exports and starts with the very fundamental question: to what extent are service firms engaged in the exporting of goods? Thus, instead of looking for the partly still invisible exports of services, we consider traditional goods exports and derive the income of individual firms, which may be in manufacturing as well as in three broad categories of services; knowledge intensive, retail and wholesale, and transport and rental.

Using an unbalanced panel of about 260,000 Swedish firm-level observations over the period 1997-2006, we show that half of the firms exporting goods are services and that they account for a substantially increasing share of the total value of exports of goods. Between 1997 and 2006 this fraction increased from 25\% to 34\%. Previous research provides little evidence of the extension of goods exports among service firms or its impact on firm performance.

Similar to manufacturing firms, services exporters are distinguishable from non-exporters in several respects: they are larger, they are more physical capital intense and human capital intense and their ownership structures are different. But there are also large variations among exporting service firms. Both in absolute size and growth rate, retail and wholesale firms are more internationalized than other service firms. 
This paper also provides strong evidence that service firms do become exporters for the same reasons as manufacturing firms. They are a self-selection of larger and more productive and high-equity firms, with more skilled labour, higher capital intensity and stronger links to multinational groups. The export productivity premium is larger for service firms than for manufacturers. No evidence is found to indicate that exporting increases the growth rate of productivity. In contrast, the annual employment growth premium from foreign markets is substantial for business services, $2 \%$ per year, while it is $0.5 \%$ for the retail and wholesale business. Employment growth among manufacturing firms also benefits from expanded market opportunities in foreign markets. The average growth rate is $0.4 \%$.

Considering the persistency of exporting behaviour, we find a considerable difference between manufacturing firms and services: $94 \%$ of manufacturing firms that export one year also export the next year. The corresponding figures for retail and wholesale, knowledge intense services and transport and rental are $86 \%, 72 \%$ and $71 \%$, respectively. Looking at persistency from the perspective of non-exporters, the pattern of difference between manufacturing and services is similar: $18 \%$ of the manufacturing firms that did not export one year started to export the following year. This can be compared with only 6-8\% of service firms that switch from non-exporting to exporting from one year to the next.

The paper is organized as follows: First, Section 2 presents the data and some initial findings from the descriptive statistics. Section 3 describes the research methodology and empirical model used. Section 4 discusses the results and Section 5 concludes the paper.

\section{Data and descriptive statistics}

The data source used in this study covers the period 1997-2006 and is obtained from Statistics Sweden (SCB). A firm is defined as a legal entity in the data material. The data set consists of balance-sheet information of about 260000 observations on Swedish firms with 10 or more employees. The downward censoring is motivated by quality issues. This data has been matched with information from other sources on exports, corporate ownership structure, human capital and firm localization. The annual number of firms varies between about 24,000 and 27,000 in the unbalanced panel. Two things should be noted about the data. First, similar to most other countries, Sweden lacks proper information on service exports at the 
firm level. However, we have access to information on all exports classified as "goods" for both services and manufacturing firms. Second, the study covers all existing firms in Sweden in the relevant size group and over the time span that we are focusing on.

In the empirical analysis we are interested in whether service firms are different exporters compared to manufacturing firms. We distinguish three broad categories for services: (i) Knowledge intensive business services, KIBS, (ii) Retail and Wholesale, RW and (iii) Transport and Rental, TR.

The left side of Table 1 reports the summary statistics for firms in our data. Two important differences between the observed units should be noted. First, we see that manufacturing firms are typically engaged in exports of goods (71\%) while service firms are not (17\% $31 \%$ ). Second the average export to sales ratio is about $18 \%$ for manufacturers. In sharp contrast the ratio is $0.5 \%$ for transport and rental firms, $1.2 \%$ for knowledge intense business firms and $2.7 \%$ for firms in the retail and wholesales business.

Figure 1: Exporting service firms as a fraction of all exporting firms

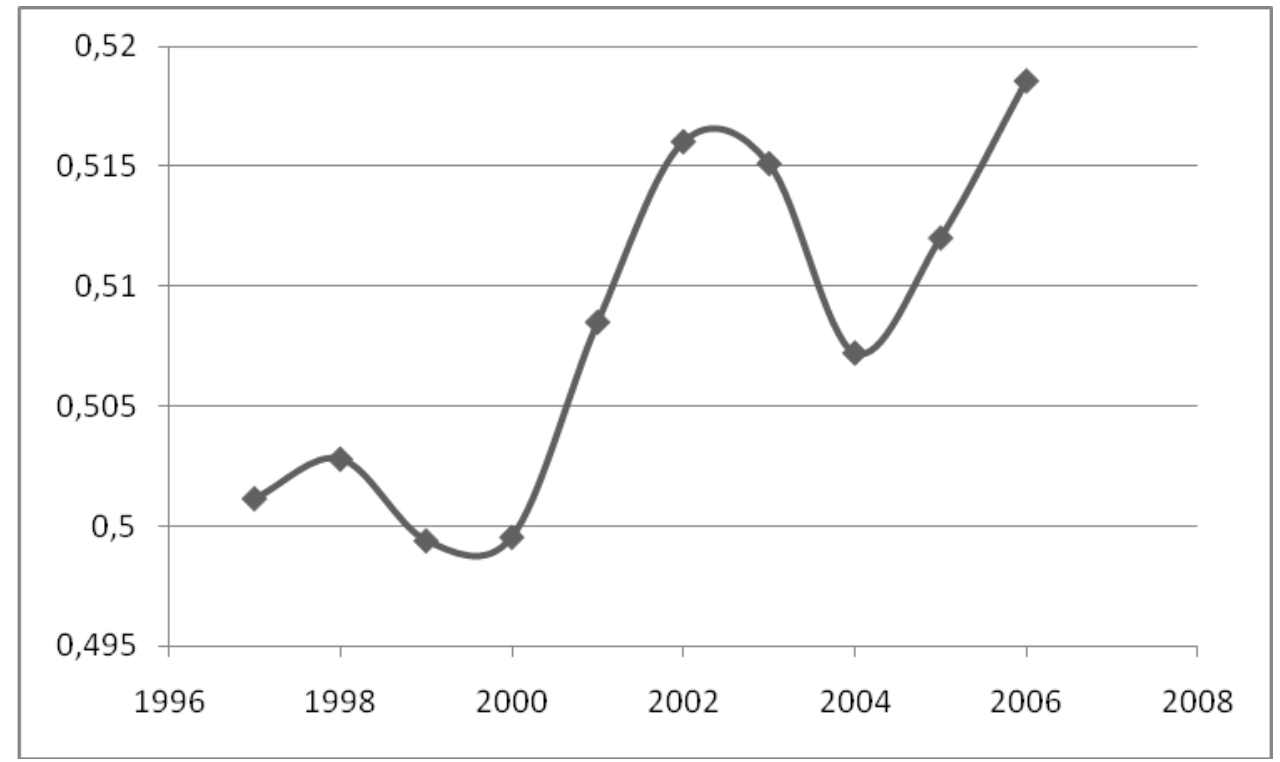

The right side of Table 1 reports statistics only for exporting firms. One interesting initial finding is that the total number of service firms exporting goods is about the same as the number of manufacturing firms. Adding a time dimension, Figure 1 above shows that this fraction was somewhat higher (52\%) in 2007 than in 1997 (50\%) 
One quarter of the output of the average exporting manufacturing firm is produced for the foreign market, which is substantially larger than the exports to sales ratio for service firms (3\%-9\%). Despite this, the number of exporting service firms is about the same as the number of exporting manufacturers. Figure 2 shows that the export value from service firms is substantial and increasing. At the beginning of the period we consider here, service firms accounted for $25 \%$ of the total export value from goods, which increased to $34 \%$ at the end of the period.

\section{Figure 2: The contribution to total export value from services 1997-2006}

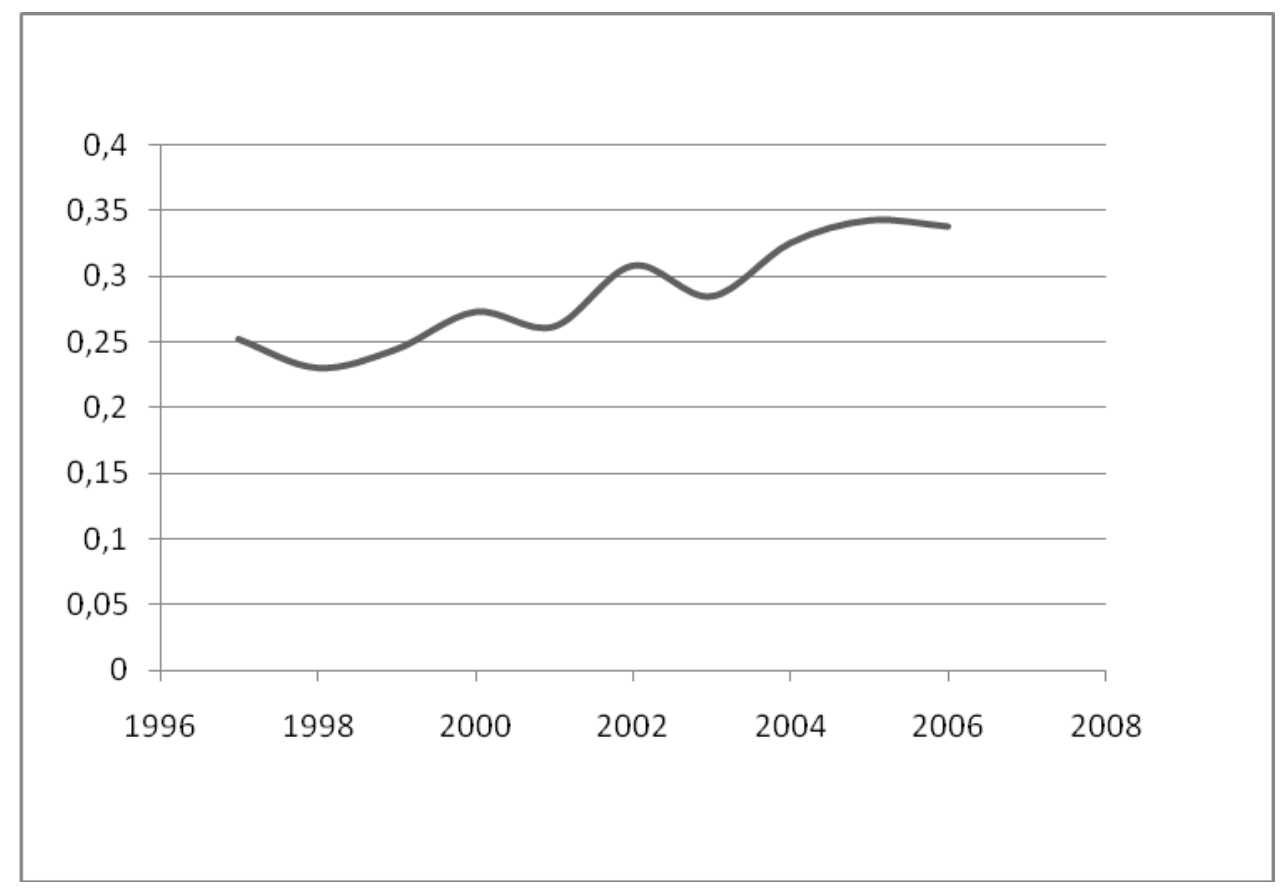

Table 1 also reports that some of the self-selection characteristics that distinguish exporters from non-exporters among manufacturing firms may also be found among services: They are larger, more knowledge and physical capital intense and more often linked to a multinational group. Regarding sales, equity and productivity no distinct conclusions can be drawn from the simple descriptive statistics.

Table 2 displays year-to-year transitions of firms serving foreign markets. The left-hand column reports that $82 \%$ of the manufacturing firm that did not export one year did not export the next year either. Inversely, we interpret this figure as a substantial degree of switching from non-exporting to exporting among manufacturing firms; nearly one out of five firms on average each year. The fraction of service firms becoming exporters is considerable smaller, 
only 6-8\%. However, in absolute numbers of firms, the extension of switching from nonexporting to exporting is about the same for manufacturing and services. The right-hand column shows that manufacturing firms are more persistent exporters than service firms. Only $6 \%$ of the manufacturing firms exit from foreign markets from one year to the next. This can be compared with nearly $30 \%$ among knowledge intense business firms and transport and rental firms. The figure for rental and wholesale is $14 \%$.

Finally, Figure 3 shows the growth of aggregate export value for the four categories of firms between 1997 and 2006. The most volatile development was among business services and transport and rental, and growth was considerable for retail and wholesale (150\%) and transport and rental (125\%). Over the whole period the growth in export value of business services was fairly modest. Considering only the latter part of the period, however, the growth was substantial. Except for the period following the ICT-crisis at the beginning of the $21 \mathrm{st}$ century, the growth rate in export value from Swedish manufacturing was stable and the total increase over the period was about $65 \%$,

Figure 3: Export value 1997-2006. Index: 1997=100

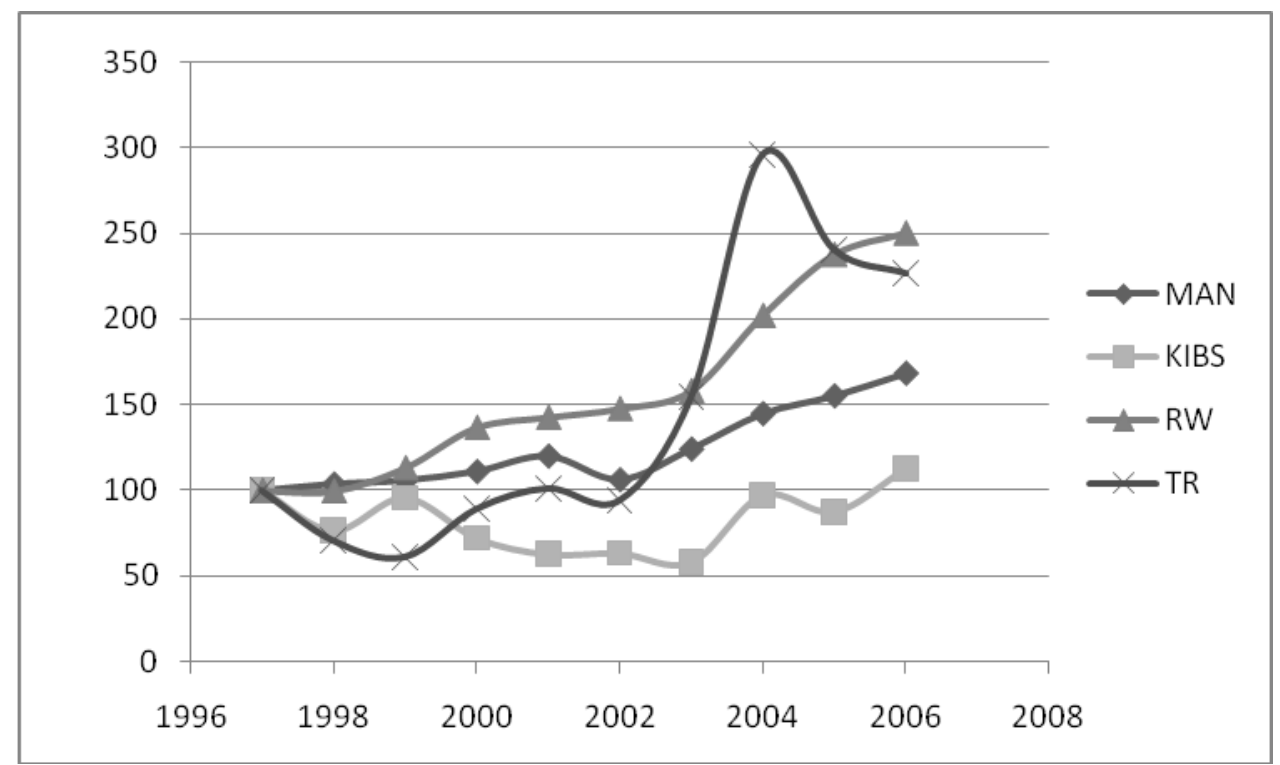




\section{Methodology}

The general model we use in this paper is a firm-specific-effect model which may be expressed as:

$$
y_{i t}=\alpha_{i}+\mathbf{x}_{\mathrm{it}}^{\prime} \boldsymbol{\beta}+\varepsilon_{i t}
$$

where $y_{i t}$ denotes firm performance by firm $i$ in year $t, \mathbf{x}_{\mathrm{it}}$ is a vector of regressors including an export dummy, $\alpha_{i}$ controls for unobserved firm-specific effects that may be fixed-effects (FE) or random-effects (RE), and $\varepsilon_{i t}$ is an idiosyncratic error.

A crucial issue is whether the fixed effects (FE) or the random effects (RE) model is the appropriate model for our regression analysis. In the FE model, the unobserved firm-specific effects $\alpha_{i}$ in equation (1) are permitted to be correlated with the regressors $\mathbf{x}_{\mathrm{it}}$. In the RE model it is assumed that $\alpha_{i}$ is purely random, implying that it is uncorrelated with the regressors.

Green (2008) stresses that even with results from the standard Hausman test available, choosing between fixed and random effects presents a bit of a dilemma. Both specifications have major shortcomings. Baltagi (2008) suggests that a rejection of the null hypothesis (difference in coefficients not systematic) should not be automatically interpreted as an adoption of the fixed effects model and a non-rejection as an adoption of the random model. Lack of identification due to non estimable time-invariant variables is the price of robustness of the FE specification, while the situation is the opposite if we choose a RE model.

In this paper we make our decision based on the data-generating process as well as particularities of the data, and we choose the FE model as our preferred estimator. The fixed effects model is an appropriate specification if we are focusing on a specific set of $\mathrm{N}$ firms, while the random effects model is more appropriate when we are drawing $\mathrm{N}$ individuals randomly from the large population (Baltagi, 2008). We observe all firms in Sweden above a particular censoring level and the data set has characteristics close to a random sample. 
Moreover, a key-variable is the binary export indicator, which is time-invariant for firms that serve foreign markets over the whole 10-year period observed. Using the FE approach, the effect of this persistent export strategy will not be possible to identify.

In order to test the robustness of the results, however, the RE estimates are compared with output from a fixed effects model. We also extend the sensitivity analysis by including three alternative estimators, pooled OLS, dynamic GMM and a matching approach.

The first model we consider is a logit firm-specific estimator with which we estimate the propensity of a firm to become engaged in export activities. This binary model specifies that

$$
\operatorname{Pr}\left(y_{i t}=1 \mid x_{i t}, \beta, \alpha_{i}\right)=\Lambda\left(\alpha_{i}+x_{i t}^{\prime} \beta\right)
$$

where $\alpha_{i}$ is the random firm specific effects and $\Lambda(\mathrm{z})=\mathrm{e}^{\mathrm{z}}\left(1+\mathrm{e}^{\mathrm{z}}\right)$. We estimate equation (1) in both the level dimension and first-difference.

\section{Variable selection}

Our study is based on extensive firm characteristics of surviving and non-surviving manufacturing and service firms in Sweden during 1997-2006. The choice of variables to include is inspired by the literature on international trade and corporate finance (see Brown et al., 2009; Himmelberg and Petersen, 1994; Mulkaly et al., 2001).

The dependent variable in the binary outcome model is 0 if firm $i$ do not export in year $t$ and 1 if it does. In the other models we are interested in how exports contribute to (i) level of labour productivity, (ii) productivity growth and (iii) employment growth among manufacturing and service firms. In the logit estimation, we wish to compare the impact of labour productivity, physical capital, human capital and financial resources available internally to the manufacturing firm versus the service firm on the decision to operate on the global market. We also include the corporate ownership, geographical location and year dummies among the determinants.

The literature has shown that productivity is a key variable separating exporters from nonexporters among manufacturing firms. We investigate whether this is true for services as well. 
Productivity is measured as value added over ordinary employment. Ordinary employment is employees with less than three years university education. The financial variables in the study are sales and equity. Omitting these variables might contribute to the export indicator variable being overly emphasized in the econometric analysis. Following the standard literature, both variables are normalized by total assets at the beginning of the period. Human capital is regarded as reflecting a firm's capacity to absorb, assimilate and develop new knowledge and technology (Bartel and Lichtenberg, 1987; Cohen and Levinthal, 1990). We measure human capital, as number of employees with at least three years university. We also control for firm size, which we measure in terms of ordinary employment. Our main interest is to investigate whether services are different exporters. Large firm are more engaged in exports, all else equal, and the descriptive statistics presented here show that manufacturing firms typically are larger than services. To a certain extent, physical capital can also be considered as a size variable.

We have included control variables for corporate ownership structure in the regression analysis. Our data permits us to distinguish between four types of corporate groups: (i) nonaffiliate firms, (ii) uni-national corporations, (iii) domestically-owned multinational enterprises (MNE) and (iv) foreign-owned MNEs. Based on the literature, we assume there are important differences between MNEs and non-MNEs regarding engagement in exports. A considerable fraction of the exports by a typical firm is also trade within the group (see Scherer, 1999; Pfaffermayr and Bellak, 2002; Klette and Kortum, 2004).

We can identify in the data the localization of the firms at municipality level, and we exploit this information in order to distinguish between firms located in the three Swedish metropolitan areas (Stockholm, Göteborg and Malmö) and firms located in other regional areas. Finally, we include year dummies to capture unobservable time-varying macroeconomic shocks common to all firms.

\section{Empirical results}

The results of the empirical analysis are presented in Tables 3-6. A robustness check of the model specification is reported in the appendix. Table 4 gives the estimates from the binary outcome model and the dependent variable is export. Table 4 estimates the export premium, 
showing the difference in the level of labour productivity between exporters and nonexporters in the four different subsamples considered, controlling for the sales-to-asset ratio, the equity-to-asset ratio, physical capital, human capital size, corporate ownership structure, and localization for the period 1997-2006. Tables 5 and 6 explain growth of labour productivity and growth of employment, respectively, as a function of the export indicator and the covariates modelled in first difference. Tables A-D in Appendix estimates the export premium using (i) a fixed effects model, (ii) a pooled OLS, (iii) the Arellano-Bond two-step GMM-estimator and (iv) an average treatment effect matching estimator.

\subsection{Determinants of selling on foreign markets}

Our first model considers the determinants of export for manufacturing and service firms. Comparing the results for the four subsamples, Table 3 reports that the point estimates for firm size and multinational company are positive and highly significant across the samples. However, size seems to be more important for manufacturing than for service firms. In conjunction with a growing body of studies on exporting manufacturing firms, we find that the level of productivity and prior market success are positively associated with the decision to enter or stay in the export market. In this paper we measure success in terms of internal financial capacity and the variable is equity normalized for total assets. Our results concerning productivity and equity suggest that the finding that exporters are better than non-exporters is also true for business services and retail and wholesale firms. However, no such link is found for firms in the transport and rental business.

Skill (human capital) and physical capital intensity correlate positively and significantly with the decision to service foreign markets for manufacturing, KIBS and retail and wholesale. The point estimates for transport and rental are positive but not significant. The only systematic differences between manufacturing and services reported in Table 2 concern the regional variables. Being located in one or more of the three Swedish metropolitan areas correlates negatively with manufacturing firms' propensity to export. The result is the opposite for service firms. 


\subsection{Export premium on labour productivity}

Table 4 presents the results for the productivity premium from the random effects model. Controlling for sales to assets, equity to assets, human capital, physical capital, firm size, corporate ownership structure and time trend, Row 1 suggests the presence of an export premium on the level of labour productivity for both manufacturing and service firms. The size of the estimate is about 0.02 for the typical firms in manufacturing and in the transport and rental business. Interestingly, the size of the estimate is considerably larger for retail and wholesale, which was the fastest growing export area in Sweden during the period we consider here. The coefficient estimate is 0.08 . The estimated premium for knowledge intense business services is also quite sizeable, $0.04 \%$. The coefficient estimates are highly significant for manufacturing, business service and retail and wholesale. The result for transport and rental is significant at the $5 \%$ level.

The table reports a high degree of similarity between manufacturers and services regarding several of the controls: Sales-to-assets, equity-to-assets, human capital, being a part of a multinational company and being located in the Swedish capital Stockholm correlates positively and highly significantly with labour productivity.

\subsection{First-difference results}

Table 3 suggests that superior firms probably become exporters and Table 4 reports an instantaneous export premium on labour productivity corresponding to $2-8 \%$ for both manufacturing and service producers. Table 5 considers the growth effect of being present on foreign markets. Similar to Bernard and Jensen (1999) and a large number of other studies in this area, no additional positive effect from export in terms of higher productivity growth can be found for manufacturing firms. The size of the coefficient is negligible and the estimate is non-significant. The results are the same for the three service regressions. How can the weak link between exports and productivity growth be explained? 
The link between exports and employment growth is shown in Table 6. In contrast to productivity growth, the elasticity of job growth rate with respect to exports is and significant for both KIBS and retail and wholesale. The magnitude of the growth premium is substantial for business services, $2 \%$ per year, and $0.5 \%$ for the retail and wholesale business. Employment growth among manufacturing firms also benefits from expanded market opportunities in foreign markets. The point estimate is significant at the $10 \%$ level and the order of magnitude of the estimates is $0.4 \%$.

\subsection{Sensitivity analysis}

Tables 3-6 report results where the firm specific effects are treated as uncorrelated with other regressors. The results may therefore suffer from inconsistency if the unobservable individual firm specific effect is correlated with any one of the explanatory variables. But the fixed effects model also has unattractive shortcomings. First, in short panels, the FE estimator of the individual effects is not consistent (Se Baltagi 2008). Second, if the true model contains timeinvariant variables, elimination of these relevant variables will result in omission variable bias. In the present case we have one additional problem with the FE approach. As the yearto-year transition figures in Table 2 show, the individual firms exhibit a substantial persistency in their decision on whether to serve foreign markets or not: more than $80 \%$ of the firms who did not export one year did not export the next year either, and more than $70 \%$ of the firms that did export one year also exported the next year. Applying the FE estimator to the binary outcome model, reported in Table 3, would give results only for firms that are observed as both exporters and non-exporters during the period 1997-2006. Persistent exporters and persistent non-exporters will not be included in the regression. These two groups correspond to approximately $3 / 4$ of the sample.

Consider then our results presented in the Appendix. The key-variable is the export-dummy. Andersson and Lööf (2009) show that persistent exporters are distinguished from nonexporters and temporary exporters. They find no relationship between exports and productivity for temporary exporters. Only persistent exporters with high export-intensity benefit from serving foreign markets. However, in the FE-model the effect of being a persistent exporter is wiped out since it is a constant term for these firms. As could be expected, Table A in the Appendix shows no, or only a weak, correlation between exports and 
productivity. In contrast, the pooled OLS (Table B) ${ }^{1}$, the dynamic Arellano-Bond estimator (Table C) and the matching estimator (Table D) report results close to the RE-estimates shown in Table 4.

Thus, there are robust results suggesting that the export premium is substantial for knowledge intensive business firms and for retail and wholesale firms. Moreover, it is larger than the premium for manufacturing firms. No impact of exports on productivity can be found when transport and rental services are considered.

\section{Conclusions}

This paper asks if services are different exporters and begins by showing that services account for a substantial and increasing fraction of the total value from goods exports. It uses an unbalanced panel of about 260000 Swedish firm level observations over the period 19972006. The data contains observations on all firms with 10 or more employees from four broad categories of the Swedish economy: manufacturing, knowledge intense business services, retail and wholesale and transport. More than 50\% of the firms exporting goods are services and their share of the export value increased from 25\% to 34\% between 1997 and 2006.

We then show that services become exporters for the same reasons as manufacturing firms. They are a self-selection of larger, more productive and high-equity firms, with more skilled labour, higher capital intensity and stronger links to multinational groups.

In so far as the persistency of exporting behaviour is concerned, we find a considerable difference between manufacturing firms and services: $94 \%$ of manufacturing firms that exported one year also exported the next year. The corresponding figures for retail and wholesale, knowledge intense services and transport and rental are $86 \%, 72 \%$ and $71 \%$, respectively. Looking at persistency from the perspective of non-exporters, the pattern of difference between manufacturing and services is similar: $18 \%$ of the manufacturing firms who did not export one year started to export the following year. This can be compared with

\footnotetext{
${ }^{1}$ Pooled estimators are consistent if the RE-model is appropriate and are inconsistent if the FE-model is appropriate.
} 
only 6-8\% switches of service firms from non-exporting to exporting from one year to the next.

Finally, we compare the export productivity premium and the export employment premium for manufacturers and services. The export productivity premium is larger for service firms than for manufacturers. No evidence is found to indicate that exporting increases the growth rate of productivity. In contrast, the annual employment growth premium from exporting is substantial for business services, $2 \%$ per year, while it is $0.5 \%$ for the retail and wholesale business. Employment growth among manufacturing firms also benefits from expanded market opportunities in foreign markets. The average growth rate is $0.4 \%$. Exporting has no significant influence on the employment growth of transport and rental firms. 


\section{REFERENCES}

\section{References at end of the paper:}

Freeman, R.B. (1994): "How labor fares in advanced economies," in Working Under Different Rules, edited by R.B. Freeman, New York, Russell Sage Foundation, 1-28.

Freeman, R.B. (1995): “Are your wages set in Bejing?," Journal of Economic Perspectives 9, 1532.

Garrison, R. / Kirzner I. (1987): "Von Hayek, Friedrich August," in The New Palgrave: A Dictionary of Economics, edited by J. Eatwell, M. Milgate, and P. Newman, Volume 2, London, Macmillan, 609-614.

Gwartney, J. / Lawson, R. (2003): "The concept and measurement of economic freedom," European Journal of Political Economy 19, 405-430.

Gwartney, J. / Lawson R. (2004): Economic Freedom of the World, 2004: Annual Report, Vancouver, B.C., Fraser Institute.

Andersson, M./ Lööf, H. (2009): "Learning-by-Exporting Revisited, the role of intensity and persistence,” Scandinavian Journal of Economics, 111(3), 893-916.

Baltagi, H. B. (2008): "Econometric Analysis of panel Data," John Wiley \& Sons, Ltd.

Mulkaly, B./Hall, B. H./Mairesse, J. (2001): "Firm Level Investment and R\&D in France and the United States: A Comparison," NBER Working Paper 8048.

Bernard, A. B./Jensen, J. B. (1999): "Exceptional exporter performance: cause, effect, or both?,"Journal of International Economics, 47, 1-25.

Brown, J. R./Fazzari, S. M./Petersen, B. C. (2009): "Financing Innovation and Growth: Cashflow, External Equity, and the 1990s R\&D Boom," Journal of Finance, 64, 151-185.

Cohen, W./Levinthal, D. A. (1990): “Absorptive Capacity - a new perspective on learning and innovation," Administrative Science Quarterly, 35, 128-152.

Himmelberg, C. P./Petersen, B. C. (1994): "R\&D and Internal Finance: A Panel Study of Small Firms in High-Tech Industries," Review of Economics and Statistics, 76, 38-51.

Greene, W. H. (2008): “Econometric Analysis,” Pearson Prentice Hall, sixth edition.

Klette, T. J./Kortum, S. (2004): "Innovating Firms and Aggregate Innovation," Journal of Political Economy, 112, 896-1018.

Mulkaly, B./Hall, B. H./Mairesse, J. (2001): "Firm Level Investment and R\&D in France and the United States: A Comparison," NBER Working Paper 8048.

Pfaffermayr, M./Bellak, C. (2002): "Why Foreign-owned Firms are Different: a conceptual framework and empirical evidence for Austria", Foreign-owned Firms: are they different?, edited by R. Jungnickel , Palgrave Macmillan, 13-57. 
Table 1: Descriptive statistics, firm characteristics.

\begin{tabular}{|c|c|c|c|c|c|c|c|c|}
\hline & \multicolumn{4}{|c|}{ All firms } & \multicolumn{4}{|c|}{ Exporters } \\
\hline & MAN & KIBS & RW & TR & MAN & KIBS & RW & $\mathrm{TR}$ \\
\hline Observations & 70,114 & 41,946 & 116,284 & 31,106 & 49,008 & 9,347 & 35,206 & 5,131 \\
\hline Exporters, share & $\begin{array}{c}0.706 \\
(0.455)\end{array}$ & $\begin{array}{c}0.227 \\
(0.419)\end{array}$ & $\begin{array}{c}0.306 \\
(0.460)\end{array}$ & $\begin{array}{c}0.169 \\
(0.374)\end{array}$ & 1.00 & 1.00 & 1.00 & 1.00 \\
\hline Export/Sales & $\begin{array}{c}0.177 \\
(0.263)\end{array}$ & $\begin{array}{c}0.012 \\
(0.788)\end{array}$ & $\begin{array}{c}0.027 \\
(0.104)\end{array}$ & $\begin{array}{c}0.005 \\
(0.046)\end{array}$ & $\begin{array}{c}0.251 \\
(0.282)\end{array}$ & $\begin{array}{c}0.054 \\
(0.159)\end{array}$ & $\begin{array}{c}0.089 \\
(0.173)\end{array}$ & $\begin{array}{c}0.029 \\
(0.108)\end{array}$ \\
\hline Sales/TA ${ }_{t-1}{ }^{a}$ & $\begin{array}{c}2.14 \\
(1.21)\end{array}$ & $\begin{array}{c}3.49 \\
(1.33)\end{array}$ & $\begin{array}{c}3.26 \\
(1.56)\end{array}$ & $\begin{array}{c}1.52 \\
(2.02)\end{array}$ & $\begin{array}{c}2.11 \\
(1.16)\end{array}$ & $\begin{array}{c}3.30 \\
(1.34)\end{array}$ & $\begin{array}{c}3.55 \\
(1.49)\end{array}$ & $\begin{array}{c}2.41 \\
(2.06)\end{array}$ \\
\hline Equity/TA ${ }_{t-1}{ }^{a}$ & $\begin{array}{l}-0.03 \\
(1.65)\end{array}$ & $\begin{array}{c}1.10 \\
(1.69)\end{array}$ & $\begin{array}{c}0.61 \\
(1.75)\end{array}$ & $\begin{array}{c}-0.90 \\
(1.96)\end{array}$ & $\begin{array}{c}0.01 \\
(1.60)\end{array}$ & $\begin{array}{c}1.04 \\
(1.89)\end{array}$ & $\begin{array}{c}1.14 \\
(1.75)\end{array}$ & $\begin{array}{c}-0.34 \\
(2.39)\end{array}$ \\
\hline Value added/emp ${ }^{a}$ & $\begin{array}{c}3.92 \\
(0.41)\end{array}$ & $\begin{array}{c}4.24 \\
(1.02)\end{array}$ & $\begin{array}{c}3.86 \\
(0.59)\end{array}$ & $\begin{array}{c}4.06 \\
(0.81)\end{array}$ & $\begin{array}{c}3.92 \\
(0.46)\end{array}$ & $\begin{array}{c}4.05 \\
(0.63)\end{array}$ & $\begin{array}{c}4.06 \\
(0.56)\end{array}$ & $\begin{array}{c}4.03 \\
(0.70)\end{array}$ \\
\hline Employment & $\begin{array}{c}88 \\
(452)\end{array}$ & $\begin{array}{c}53 \\
(225)\end{array}$ & $\begin{array}{c}42 \\
(234)\end{array}$ & $\begin{array}{c}75 \\
(792)\end{array}$ & $\begin{array}{c}114 \\
(533)\end{array}$ & $\begin{array}{c}110 \\
(366)\end{array}$ & $\begin{array}{c}77 \\
(4.12)\end{array}$ & $\begin{array}{c}241 \\
(1,6529\end{array}$ \\
\hline Total assets ${ }^{a}$ & $\begin{array}{c}8.42 \\
(1.82)\end{array}$ & $\begin{array}{c}6.50 \\
(1.58)\end{array}$ & $\begin{array}{c}7.25 \\
(1.81)\end{array}$ & $\begin{array}{c}8.83 \\
(2.39)\end{array}$ & $\begin{array}{c}8.79 \\
(1.80)\end{array}$ & $\begin{array}{l}7.48 \\
1.66)\end{array}$ & $\begin{array}{c}7.71 \\
(1.18)\end{array}$ & $\begin{array}{c}8.92 \\
(2.34)\end{array}$ \\
\hline Physical capital $^{\text {a }}$ & $\begin{array}{c}4.88 \\
(1.52)\end{array}$ & $\begin{array}{c}3.05 \\
(1.77)\end{array}$ & $\begin{array}{c}4.07 \\
(1.79)\end{array}$ & $\begin{array}{c}5.44 \\
(2.28)\end{array}$ & $\begin{array}{c}5.05 \\
(1.39)\end{array}$ & $\begin{array}{c}3.70 \\
(1.57)\end{array}$ & $\begin{array}{c}4.27 \\
(1.59)\end{array}$ & $\begin{array}{c}4.98 \\
(2.10)\end{array}$ \\
\hline Human capital $^{\text {b }}$ & $\begin{array}{c}0.052 \\
(0.092)\end{array}$ & $\begin{array}{c}0.270 \\
(0.256)\end{array}$ & $\begin{array}{c}0.046 \\
(0.089)\end{array}$ & $\begin{array}{c}0.060 \\
(0.114)\end{array}$ & $\begin{array}{c}0.058 \\
(0.093)\end{array}$ & $\begin{array}{c}0.309 \\
(0.245)\end{array}$ & $\begin{array}{c}0.086 \\
(0.115)\end{array}$ & $\begin{array}{c}0.094 \\
(0.143)\end{array}$ \\
\hline Non-affiliate & 0.37 & 0.40 & 0.47 & 0.47 & 0.29 & 0.26 & 0.26 & 0.28 \\
\hline Uninational & 0.32 & 0.32 & 0.34 & 0.38 & 0.30 & 0.24 & 0.29 & 0.29 \\
\hline Domestic MNE & 0.19 & 0.16 & 0.09 & 0.08 & 0.24 & 0.27 & 0.21 & 0.21 \\
\hline Foreign MNE & 0.12 & 0.12 & 0.10 & 0.07 & 0.16 & 0.23 & 0.24 & 0.22 \\
\hline Metro-Stlm & 0.13 & 0.47 & 0.27 & 0.24 & 0.12 & 0.50 & 0.34 & 0.33 \\
\hline Metro-Gbg & 0.09 & 0.12 & 0.12 & 0.13 & 0.09 & 0.14 & 0.16 & 0.21 \\
\hline Metro-Malmo & 0.06 & 0.07 & 0.07 & 0.06 & 0.06 & 0.08 & 0.09 & 0.07 \\
\hline Non-metropolitan & 0.72 & 0.34 & 0.53 & 0.57 & 0.73 & 0.28 & 0.41 & 0.39 \\
\hline
\end{tabular}

Notes:

Manufacturing (MAN), Knowledge intense business services (KIBS), Retail and Wholesale (RW), Transport and Rental (TR).

Mean and standard deviation between parentheses
(a) Logarithm
(b) Employees with 3 years education or more/Total employment 
Table 2: Year-to-year transitions in whether a firm serves foreign markets

\begin{tabular}{|l|c|c|}
\hline \hline & $\begin{array}{c}\text { Fraction of firms who did not export one } \\
\text { year and did not export the next year }\end{array}$ & $\begin{array}{c}\text { Fraction of firms that did export one year } \\
\text { and also exported the next year }\end{array}$ \\
\hline MA & 0.824 & 0.940 \\
KIBS & 0.915 & 0.723 \\
RW & 0.935 & 0.860 \\
TR & 0.934 & 0.705 \\
\hline \hline
\end{tabular}

Notes:

Manufacturing (MAN), Knowledge intense business services (KIBS), Retail and Wholesale (RW), Transport and Rental (TR). 
Table 3: Binary outcome model. Random effects logit estimation.

Dependent variable is the propensity to export.

\begin{tabular}{|c|c|c|c|c|}
\hline & MAN & KIBS & RW & $\mathrm{TR}$ \\
\hline Value added/emp ${ }^{1}$ & $\begin{array}{l}0.360 \\
(0.072) * * *\end{array}$ & $\begin{array}{l}0.182 \\
(0.043)^{* * *}\end{array}$ & $\begin{array}{l}1.166 \\
(0.054)^{* * *}\end{array}$ & $\begin{array}{l}0.025 \\
(0.071)\end{array}$ \\
\hline Sales/TA ${ }_{\mathrm{t}-1} 1$ & $\begin{array}{l}-0.162 \\
(0.040)^{* * *}\end{array}$ & $\begin{array}{l}-0.214 \\
(0.036)^{* * *}\end{array}$ & $\begin{array}{l}-0.019 \\
(0.028)\end{array}$ & $\begin{array}{l}0.301 \\
(0.039)^{* * *}\end{array}$ \\
\hline Equity/TA ${ }_{\mathrm{t}-1}^{1}$ & $\begin{array}{l}0.174 \\
(0.025)^{* * *}\end{array}$ & $\begin{array}{l}0.115 \\
(0.023)^{* * *}\end{array}$ & $\begin{array}{l}0.291 \\
(0.019)^{* * *}\end{array}$ & $\begin{array}{l}-0.027 \\
(0.026)\end{array}$ \\
\hline Tot assets/emp ${ }^{1}$ & $\begin{array}{l}0.238 \\
(0.028)^{* * *}\end{array}$ & $\begin{array}{l}0.327 \\
(0.026)^{* * *}\end{array}$ & $\begin{array}{l}0.159 \\
(0.019)^{* * *}\end{array}$ & $\begin{array}{l}0.043 \\
(0.030)\end{array}$ \\
\hline Human cap & $\begin{array}{l}0.187 \\
(0.024)^{* * *}\end{array}$ & $\begin{array}{l}0.097 \\
(0.027)^{* * *}\end{array}$ & $\begin{array}{l}0.395 \\
(0.019)^{* * *}\end{array}$ & $\begin{array}{l}0.002 \\
(0.031)\end{array}$ \\
\hline Firm size $^{1}$ & $\begin{array}{l}1.894 \\
(0.069)^{* * *}\end{array}$ & $\begin{array}{l}0.985 \\
(0.057)^{* * *}\end{array}$ & $\begin{array}{l}0.879 \\
(0.048)^{* * *}\end{array}$ & $\begin{array}{l}0.917 \\
(0.068)^{* * * *}\end{array}$ \\
\hline UNI-NAT $^{2}$ & $\begin{array}{l}0.452 \\
(0.078)^{* * *}\end{array}$ & $\begin{array}{l}0.061 \\
(0.085)\end{array}$ & $\begin{array}{l}0.486 \\
(0.059)^{* * *}\end{array}$ & $\begin{array}{l}0.251 \\
(0.103)^{* *}\end{array}$ \\
\hline Dom-MNE ${ }^{2}$ & $\begin{array}{l}1.459 \\
(0.116)^{* * *}\end{array}$ & $\begin{array}{l}1.180 \\
(0.103)^{* * *}\end{array}$ & $\begin{array}{l}2.591 \\
(0.097)^{* * *}\end{array}$ & $\begin{array}{l}1.490 \\
(0.158)^{* * *}\end{array}$ \\
\hline For-MNE ${ }^{2}$ & $\begin{array}{l}1.976 \\
(0.152)^{* * *}\end{array}$ & $\begin{array}{l}1.390 \\
(0.111)^{* * *}\end{array}$ & $\begin{array}{l}2.944 \\
(0.097)^{* * *}\end{array}$ & $\begin{array}{l}2.003 \\
(0.170)^{* * *}\end{array}$ \\
\hline Metro-Stlm ${ }^{3}$ & $\begin{array}{l}-0.523 \\
(0.150)^{* * *}\end{array}$ & $\begin{array}{l}0.356 \\
(0.100)^{* * *}\end{array}$ & $\begin{array}{l}0.749 \\
(0.081)^{* * *}\end{array}$ & $\begin{array}{l}0.642 \\
(0.135)^{* * *}\end{array}$ \\
\hline Metro-Gbg ${ }^{3}$ & $\begin{array}{l}0.197 \\
(0.182)\end{array}$ & $\begin{array}{l}0.709 \\
(0.141)^{* * *}\end{array}$ & $\begin{array}{l}1.374 \\
(0.106)^{* * *}\end{array}$ & $\begin{array}{l}1.154 \\
(0.164)^{* * *}\end{array}$ \\
\hline Metro-Malmö $^{3}$ & $\begin{array}{l}-0.232 \\
(0.214)\end{array}$ & $\begin{array}{l}0.501 \\
(0.174)^{* * *}\end{array}$ & $\begin{array}{l}0.790 \\
(0.131)^{* * *}\end{array}$ & $\begin{array}{l}0.527 \\
(0.225)^{* *}\end{array}$ \\
\hline $\begin{array}{l}\text { Observations } \\
\text { Unique firms }\end{array}$ & $\begin{array}{l}55,333 \\
10294\end{array}$ & $\begin{array}{l}28,382 \\
7473\end{array}$ & $\begin{array}{l}85,488 \\
18034\end{array}$ & $\begin{array}{l}22,573 \\
4926\end{array}$ \\
\hline
\end{tabular}

Notes:

Manufacturing (MAN), Knowledge intense business services (KIBS), Retail and Wholesale (RW), Transport and Rental (TR).

Standard errors within parentheses. * Significant at 10\%; ** significant at 5\%; *** significant at $1 \%$

(1) In logs

(2 Reference is non-affiliate firms

(3) Reference is non-metropolitan firms

Year dummies are included in the regressions 
Table 4. Random effects model. Dependent variable is labour productivity (log)

\begin{tabular}{|c|c|c|c|c|}
\hline & MAN & KIBS & RW & TR \\
\hline Exports & $\begin{array}{l}0.024 \\
(0.004)^{* * *}\end{array}$ & $\begin{array}{l}0.036 \\
(0.013) * * *\end{array}$ & $\begin{array}{l}0.085 \\
(0.005)^{* * *}\end{array}$ & $\begin{array}{l}0.018 \\
(0.009)^{*}\end{array}$ \\
\hline Sales/TA ${ }_{\mathrm{t}-1}$ & $\begin{array}{l}0.072 \\
(0.006)^{* * *}\end{array}$ & $\begin{array}{l}0.139 \\
(0.010)^{* * *}\end{array}$ & $\begin{array}{l}0.028 \\
(0.003)^{* * *}\end{array}$ & $\begin{array}{l}0.027 \\
(0.008) * * *\end{array}$ \\
\hline Equity/TA ${ }_{\mathrm{t}-1}$ & $\begin{array}{l}0.029 \\
(0.003)^{* * *}\end{array}$ & $\begin{array}{l}0.001 \\
(0.005)\end{array}$ & $\begin{array}{l}0.035 \\
(0.002)^{* * *}\end{array}$ & $\begin{array}{l}0.013 \\
(0.004)^{* * *}\end{array}$ \\
\hline Physical capital & $\begin{array}{l}0.103 \\
(0.004)^{* * *}\end{array}$ & $\begin{array}{l}0.105 \\
(0.008)^{* * *}\end{array}$ & $\begin{array}{l}0.081 \\
(0.003)^{* * *}\end{array}$ & $\begin{array}{l}0.125 \\
(0.006) * * *\end{array}$ \\
\hline Human capital & $\begin{array}{l}0.047 \\
(0.002)^{* * *}\end{array}$ & $\begin{array}{l}0.159 \\
(0.005)^{* * *}\end{array}$ & $\begin{array}{l}0.055 \\
(0.002)^{* * *}\end{array}$ & $\begin{array}{l}0.056 \\
(0.005)^{* * * *}\end{array}$ \\
\hline Firm size & $\begin{array}{l}-0.064 \\
(0.007)^{* * *}\end{array}$ & $\begin{array}{l}-0.222 \\
(0.014) * * *\end{array}$ & $\begin{array}{l}-0.112 \\
(0.006)^{* * *}\end{array}$ & $\begin{array}{l}-0.170 \\
(0.013)^{* * * *}\end{array}$ \\
\hline UNI-NAT $^{1}$ & $\begin{array}{l}0.015 \\
(0.006)^{* *}\end{array}$ & $\begin{array}{l}0.047 \\
(0.019)^{* *}\end{array}$ & $\begin{array}{l}0.048 \\
(0.005)^{* * *}\end{array}$ & $\begin{array}{l}0.074 \\
(0.010)^{* * * *}\end{array}$ \\
\hline Dom-MNE $^{1}$ & $\begin{array}{l}0.061 \\
(0.010)^{* * *}\end{array}$ & $\begin{array}{l}0.138 \\
(0.025)^{* * *}\end{array}$ & $\begin{array}{l}0.118 \\
(0.009)^{* * *}\end{array}$ & $\begin{array}{l}0.165 \\
(0.022)^{* * *}\end{array}$ \\
\hline For-MNE $^{1}$ & $\begin{array}{l}0.071 \\
(0.012)^{* * *}\end{array}$ & $\begin{array}{l}0.159 \\
(0.029)^{* * *}\end{array}$ & $\begin{array}{l}0.149 \\
(0.010)^{* * *}\end{array}$ & $\begin{array}{l}0.159 \\
(0.027)^{* * *}\end{array}$ \\
\hline Metro-Stlm ${ }^{2}$ & $\begin{array}{l}0.073 \\
(0.013) * * *\end{array}$ & $\begin{array}{l}0.080 \\
(0.019)^{* * *}\end{array}$ & $\begin{array}{l}0.065 \\
(0.008)^{* * *}\end{array}$ & $\begin{array}{l}0.116 \\
(0.022)^{* * * *}\end{array}$ \\
\hline Metro-Gbg ${ }^{2}$ & $\begin{array}{l}0.049 \\
(0.016) * * *\end{array}$ & $\begin{array}{l}0.077 \\
(0.035)^{* *}\end{array}$ & $\begin{array}{l}0.053 \\
(0.011)^{* * *}\end{array}$ & $\begin{array}{l}0.094 \\
(0.027)^{* * *}\end{array}$ \\
\hline Metro-Malmö $^{2}$ & $\begin{array}{l}0.031 \\
(0.020)\end{array}$ & $\begin{array}{l}-0.025 \\
(0.070)\end{array}$ & $\begin{array}{l}0.026 \\
(0.011)^{* *}\end{array}$ & $\begin{array}{l}0.036 \\
(0.033)\end{array}$ \\
\hline $\begin{array}{l}\text { Observations } \\
\text { Unique firms }\end{array}$ & $\begin{array}{l}55343 \\
10294\end{array}$ & $\begin{array}{l}28421 \\
7473\end{array}$ & $\begin{array}{l}85542 \\
18034\end{array}$ & $\begin{array}{l}22595 \\
4926\end{array}$ \\
\hline
\end{tabular}

\section{Notes:}

Manufacturing (MAN), Knowledge intense business services (KIBS), Retail and Wholesale (RW), Transport and Rental (TR).

Standard errors within parentheses. * Significant at 10\%; ** significant at 5\%; *** significant at $1 \%$

(1) Reference is non-affiliate firms

(2) Reference is non-metropolitan firms

Year dummies are included in the regressions 
Table 5. Random effects model. Dependent variable is Productivity growth

\begin{tabular}{|c|c|c|c|c|}
\hline & MAN & KIBS & RW & TR \\
\hline Exports & $\begin{array}{l}0.002 \\
(0.605)\end{array}$ & $\begin{array}{l}0.010 \\
(0.191)\end{array}$ & $\begin{array}{l}-0.002 \\
(0.544)\end{array}$ & $\begin{array}{l}-0.002 \\
(0.818)\end{array}$ \\
\hline$\Delta$ Sales/TA ${ }_{\mathrm{t}-1}$ & $\begin{array}{l}0.128 \\
(0.000)^{* * *}\end{array}$ & $\begin{array}{l}0.181 \\
(0.000)^{* * *}\end{array}$ & $\begin{array}{l}0.089 \\
(0.000)^{* * *}\end{array}$ & $\begin{array}{l}0.171 \\
(0.000)^{* * *}\end{array}$ \\
\hline$\Delta$ Equity/TA ${ }_{\mathrm{t}-1}$ & $\begin{array}{l}-0.000 \\
(0.955)\end{array}$ & $\begin{array}{l}-0.036 \\
(0.000)^{* * *}\end{array}$ & $\begin{array}{l}-0.003 \\
(0.563)\end{array}$ & $\begin{array}{l}-0.031 \\
(0.008)^{* * *}\end{array}$ \\
\hline$\Delta$ Tot assets/emp & $\begin{array}{l}0.042 \\
(0.000)^{* * *}\end{array}$ & $\begin{array}{l}0.035 \\
(0.000)^{* * *}\end{array}$ & $\begin{array}{l}0.029 \\
(0.000)^{* * *}\end{array}$ & $\begin{array}{l}0.067 \\
(0.000)^{* * *}\end{array}$ \\
\hline$\Delta$ Human cap & $\begin{array}{l}0.025 \\
(0.469)\end{array}$ & $\begin{array}{l}0.022 \\
(0.079)^{*}\end{array}$ & $\begin{array}{l}0.050 \\
(0.024) * *\end{array}$ & $\begin{array}{l}0.007 \\
(0.886)\end{array}$ \\
\hline Observations & 44872 & 20807 & 66758 & 17603 \\
\hline Number of id & 8826 & 5556 & 14638 & 3992 \\
\hline
\end{tabular}

Notes:

Manufacturing (MAN), Knowledge intense business services (KIBS), Retail and Wholesale (RW), Transport and Rental (TR).

Standard errors within parentheses. * Significant at 10\%; ** significant at 5\%; *** significant at $1 \%$

(1) Reference is non-affiliate firms

(2) Reference is non-metropolitan firms

Year dummies, firm size, corporate ownership and localization are included in the regressions 
Table 6. Random effects model. Dependent variable is Labour growth

\begin{tabular}{|l|llll|}
\hline \hline & MAN & KIBS & RW & TR \\
\hline Exports & 0.004 & 0.020 & 0.005 & -0.008 \\
& $(0.100)^{*}$ & $(0.000)^{* * *}$ & $(0.019)^{* *}$ & $(0.228)$ \\
& 0.097 & 0.109 & 0.061 & 0.064 \\
$\Delta$ Equity/TA $\mathrm{t}-1$ & $(0.000)^{* * *}$ & $(0.000)^{* * *}$ & $(0.000)^{* * *}$ & $(0.000)^{* * *}$ \\
& -0.029 & -0.031 & -0.022 & -0.016 \\
$\Delta$ Tot assets/emp & $(0.000)^{* * *}$ & $(0.000)^{* * *}$ & $(0.000)^{* * *}$ & $(0.000)^{* * *}$ \\
& -0.041 & -0.051 & -0.039 & -0.063 \\
$\Delta$ Human cap & $(0.000)^{* * *}$ & $(0.000)^{* * *}$ & $(0.000)^{* * *}$ & $(0.000)^{* * *}$ \\
& -0.011 & 0.041 & -0.015 & -0.016 \\
Observations & $(0.614)$ & $(0.000)^{* * *}$ & $(0.425)$ & $(0.655)$ \\
Number of id & 44872 & 20807 & 65758 & 17603 \\
\hline \hline
\end{tabular}

Notes:

Manufacturing (MAN), Knowledge intense business services (KIBS), Retail and Wholesale (RW), Transport and Rental (TR).

Standard errors within parentheses. * Significant at 10\%; ** significant at 5\%; *** significant at $1 \%$

(1) Reference is non-affiliate firms

(2) Reference is non-metropolitan firms

Year dummies, firm size, corporate ownership and localization are included in the regressions 


\section{Appendix}

Table A: Fixed effects model. Dependent variable is labour productivity (log)

\begin{tabular}{|c|c|c|c|c|}
\hline & MAN & KIBS & RW & TR \\
\hline Exports & $\begin{array}{l}0.003 \\
(0.005)\end{array}$ & $\begin{array}{l}-0.002 \\
(0.013)\end{array}$ & $\begin{array}{l}0.011 \\
(0.004) * * *\end{array}$ & $\begin{array}{l}0.015 \\
(0.008)^{*}\end{array}$ \\
\hline Sales/TA $\mathrm{t}_{\mathrm{t}-1}$ & $\begin{array}{l}0.094 \\
(0.003)^{* * *}\end{array}$ & $\begin{array}{l}0.157 \\
(0.008)^{* * *}\end{array}$ & $\begin{array}{l}0.047 \\
(0.002)^{* * *}\end{array}$ & $\begin{array}{l}0.064 \\
(0.004)^{* * *}\end{array}$ \\
\hline Equity/TA ${ }_{t-1}$ & $\begin{array}{l}0.012 \\
(0.002)^{* * *}\end{array}$ & $\begin{array}{l}-0.022 \\
(0.005)^{* * *}\end{array}$ & $\begin{array}{l}0.014 \\
(0.002)^{* * *}\end{array}$ & $\begin{array}{l}-0.005 \\
(0.003)^{* *}\end{array}$ \\
\hline Physical capital & $\begin{array}{l}0.076 \\
(0.002)^{* * * *}\end{array}$ & $\begin{array}{l}0.085 \\
(0.005)^{* * * *}\end{array}$ & $\begin{array}{l}0.056 \\
(0.001) * * *\end{array}$ & $\begin{array}{l}0.095 \\
(0.003) * * *\end{array}$ \\
\hline Human capital & $\begin{array}{l}0.027 \\
(0.002)^{* * *}\end{array}$ & $\begin{array}{l}0.075 \\
(0.006)^{* * *}\end{array}$ & $\begin{array}{l}0.032 \\
(0.001)^{* * *}\end{array}$ & $\begin{array}{l}0.035 \\
(0.003)^{* * *}\end{array}$ \\
\hline Firm size & $\begin{array}{l}-0.176 \\
(0.006) * * *\end{array}$ & $\begin{array}{l}-0.207 \\
(0.015)^{* * *}\end{array}$ & $\begin{array}{l}-0.229 \\
(0.005)^{* * *}\end{array}$ & $\begin{array}{l}-0.255 \\
(0.008)^{* * *}\end{array}$ \\
\hline UNI-NAT $^{1}$ & $\begin{array}{l}-0.004 \\
(0.006)\end{array}$ & $\begin{array}{l}-0.012 \\
(0.017)\end{array}$ & $\begin{array}{l}-0.002 \\
(0.005)\end{array}$ & $\begin{array}{l}0.012 \\
(0.010)\end{array}$ \\
\hline Dom-MNE ${ }^{1}$ & $\begin{array}{l}-0.005 \\
(0.008)\end{array}$ & $\begin{array}{l}0.015 \\
(0.024)\end{array}$ & $\begin{array}{l}-0.013 \\
(0.008)\end{array}$ & $\begin{array}{l}0.031 \\
(0.017)^{*}\end{array}$ \\
\hline For-MNE ${ }^{1}$ & $\begin{array}{l}-0.023 \\
(0.009)^{* * *}\end{array}$ & $\begin{array}{l}0.044 \\
(0.027)^{*}\end{array}$ & $\begin{array}{l}-0.007 \\
(0.008)\end{array}$ & $\begin{array}{l}0.044 \\
(0.018)^{* *}\end{array}$ \\
\hline Metro-Stlm ${ }^{2}$ & $\begin{array}{l}-0.015 \\
(0.020)\end{array}$ & $\begin{array}{l}-0.009 \\
(0.041)\end{array}$ & $\begin{array}{l}0.027 \\
(0.014)^{*}\end{array}$ & $\begin{array}{l}0.029 \\
(0.027)\end{array}$ \\
\hline Metro-Gbg ${ }^{2}$ & $\begin{array}{l}0.094 \\
(0.027)^{* * *}\end{array}$ & $\begin{array}{l}0.092 \\
(0.060)\end{array}$ & $\begin{array}{l}0.069 \\
(0.019)^{* * *}\end{array}$ & $\begin{array}{l}0.019 \\
(0.035)\end{array}$ \\
\hline Metro-Malmö ${ }^{2}$ & $\begin{array}{l}-0.048 \\
(0.029)\end{array}$ & $\begin{array}{l}-0.163 \\
(0.075)^{* *}\end{array}$ & $\begin{array}{l}0.046 \\
(0.022)^{* *}\end{array}$ & $\begin{array}{l}-0.098 \\
(0.046)^{* *}\end{array}$ \\
\hline $\begin{array}{l}\text { Observations } \\
\text { Unique firms }\end{array}$ & $\begin{array}{l}55343 \\
10294\end{array}$ & $\begin{array}{l}28421 \\
7473\end{array}$ & $\begin{array}{l}85542 \\
18034\end{array}$ & $\begin{array}{l}22595 \\
4926\end{array}$ \\
\hline
\end{tabular}

Notes:

Manufacturing (MAN), Knowledge intense business services (KIBS), Retail and Wholesale (RW), Transport and Rental (TR).

Standard errors within parentheses. * Significant at 10\%; ** significant at 5\%; *** significant at $1 \%$

(1) Reference is non-affiliate firms

(2) Reference is non-metropolitan firms

Year dummies are included in the regressions 
Table B. Pooled OLS model. Dependent variable is labour productivity (log)

\begin{tabular}{|c|c|c|c|c|}
\hline & MAN & KIBS & RW & TR \\
\hline Exports & $\begin{array}{l}0.010 \\
(0.006)^{*}\end{array}$ & $\begin{array}{l}0.058 \\
(0.017)^{* * *}\end{array}$ & $\begin{array}{l}0.119 \\
(0.006) * * *\end{array}$ & $\begin{array}{l}-0.013 \\
(0.016)\end{array}$ \\
\hline Sales/TA ${ }_{\mathrm{t}-1}$ & $\begin{array}{l}0.099 \\
(0.005)^{* * *}\end{array}$ & $\begin{array}{l}0.161 \\
(0.010)^{* * *}\end{array}$ & $\begin{array}{l}0.045 \\
(0.004)^{* * *}\end{array}$ & $\begin{array}{l}0.034 \\
(0.008)^{* * * *}\end{array}$ \\
\hline Equity/TA $\mathrm{t}_{-1}$ & $\begin{array}{l}0.043 \\
(0.003)^{* * * *}\end{array}$ & $\begin{array}{l}0.017 \\
(0.005)^{* * * *}\end{array}$ & $\begin{array}{l}0.057 \\
(0.002)^{* * *}\end{array}$ & $\begin{array}{l}0.030 \\
(0.004)^{* * * *}\end{array}$ \\
\hline Physical capital & $\begin{array}{l}0.180 \\
(0.005)^{* * * *}\end{array}$ & $\begin{array}{l}0.168 \\
(0.008)^{* * * *}\end{array}$ & $\begin{array}{l}0.145 \\
(0.003)^{* * *}\end{array}$ & $\begin{array}{l}0.228 \\
(0.007)^{* * *}\end{array}$ \\
\hline Human capital & $\begin{array}{l}0.072 \\
(0.003)^{* * *}\end{array}$ & $\begin{array}{l}0.245 \\
(0.006)^{* * *}\end{array}$ & $\begin{array}{l}0.083 \\
(0.003)^{* * *}\end{array}$ & $\begin{array}{l}0.103 \\
(0.006)^{* * * *}\end{array}$ \\
\hline Firm size & $\begin{array}{l}-0.076 \\
(0.005)^{* * *}\end{array}$ & $\begin{array}{l}-0.288 \\
(0.012)^{* * *}\end{array}$ & $\begin{array}{l}-0.091 \\
(0.005)^{* * *}\end{array}$ & $\begin{array}{l}-0.126 \\
(0.011)^{* * *}\end{array}$ \\
\hline UNI-NAT $^{1}$ & $\begin{array}{l}0.036 \\
(0.006)^{* * *}\end{array}$ & $\begin{array}{l}0.075 \\
(0.019)^{* * *}\end{array}$ & $\begin{array}{l}0.090 \\
(0.005)^{* * *}\end{array}$ & $\begin{array}{l}0.155 \\
(0.012)^{* * * *}\end{array}$ \\
\hline Dom-MNE ${ }^{1}$ & $\begin{array}{l}0.105 \\
(0.009)^{* * *}\end{array}$ & $\begin{array}{l}0.177 \\
(0.024)^{* * *}\end{array}$ & $\begin{array}{l}0.182 \\
(0.011)^{* * *}\end{array}$ & $\begin{array}{l}0.341 \\
(0.030)^{* * *}\end{array}$ \\
\hline For-MNE ${ }^{1}$ & $\begin{array}{l}0.131 \\
(0.012)^{* * *}\end{array}$ & $\begin{array}{l}0.150 \\
(0.028)^{* * *}\end{array}$ & $\begin{array}{l}0.234 \\
(0.011)^{* * *}\end{array}$ & $\begin{array}{l}0.282 \\
(0.029) * * *\end{array}$ \\
\hline Metro-Stlm ${ }^{2}$ & $\begin{array}{l}0.102 \\
(0.011)^{* * *}\end{array}$ & $\begin{array}{l}0.062 \\
(0.017)^{* * *}\end{array}$ & $\begin{array}{l}0.054 \\
(0.007)^{* * *}\end{array}$ & $\begin{array}{l}0.105 \\
(0.017)^{* * *}\end{array}$ \\
\hline Metro-Gbg ${ }^{2}$ & $\begin{array}{l}0.041 \\
(0.011)^{* * *}\end{array}$ & $\begin{array}{l}0.057 \\
(0.026)^{* *}\end{array}$ & $\begin{array}{l}0.037 \\
(0.008)^{* * *}\end{array}$ & $\begin{array}{l}0.080 \\
(0.022)^{* * *}\end{array}$ \\
\hline Metro-Malmö ${ }^{2}$ & $\begin{array}{l}0.037 \\
(0.014) * * *\end{array}$ & $\begin{array}{l}-0.040 \\
(0.034)\end{array}$ & $\begin{array}{l}-0.008 \\
(0.011)\end{array}$ & $\begin{array}{l}0.076 \\
(0.028) * * *\end{array}$ \\
\hline $\begin{array}{l}\text { Observations } \\
\text { Unique firms }\end{array}$ & $\begin{array}{l}55343 \\
10294\end{array}$ & $\begin{array}{l}28421 \\
7473\end{array}$ & $\begin{array}{l}85542 \\
18034\end{array}$ & $\begin{array}{l}22595 \\
4926\end{array}$ \\
\hline
\end{tabular}

Notes:

Manufacturing (MAN), Knowledge intense business services (KIBS), Retail and Wholesale (RW), Transport and Rental (TR).

Robust standard errors in parentheses $*$ Significant at $10 \% ; * *$ significant at $5 \% ; * * *$ significant at $1 \%$

(1) Reference is non-affiliate firms

(2) Reference is non-metropolitan firms

Year dummies are included in the regressions 
Table C. Arellano-Bond dynamic GMM-estimator. Two-step. Dependent variable is labour productivity $(\log )$

\begin{tabular}{|c|c|c|c|c|}
\hline & MAN & KIBS & RW & TR \\
\hline Exports & $\begin{array}{l}0.030 \\
(0.006)^{* * *}\end{array}$ & $\begin{array}{l}0.071 \\
(0.016)^{* * *}\end{array}$ & $\begin{array}{l}0.092 \\
(0.009)^{* * *}\end{array}$ & $\begin{array}{l}-0.007 \\
(0.010)\end{array}$ \\
\hline Lab prod ${ }_{t-1}$ & $\begin{array}{l}0.382 \\
(0.024)^{* * *}\end{array}$ & $\begin{array}{l}0.493 \\
(0.054) * * *\end{array}$ & $\begin{array}{l}0.309 \\
(0.017)^{* * *}\end{array}$ & $\begin{array}{l}0.336 \\
(0.040)^{* * *}\end{array}$ \\
\hline Human capital & $\begin{array}{l}0.054 \\
(0.034)\end{array}$ & $\begin{array}{l}0.073 \\
(0.034)^{* *}\end{array}$ & $\begin{array}{l}0.143 \\
(0.025)^{* * *}\end{array}$ & $\begin{array}{l}0.144 \\
(0.037)^{* * *}\end{array}$ \\
\hline Human capital $t-1$ & $\begin{array}{l}-0.026 \\
(0.020)\end{array}$ & $\begin{array}{l}-0.006 \\
(0.020)\end{array}$ & $\begin{array}{l}-0.059 \\
(0.014) * * *\end{array}$ & $\begin{array}{l}-0.071 \\
(0.020)^{* * *}\end{array}$ \\
\hline Physical capital & $\begin{array}{l}0.120 \\
(0.025)^{* * *}\end{array}$ & $\begin{array}{l}0.067 \\
(0.036)^{*}\end{array}$ & $\begin{array}{l}0.092 \\
(0.015)^{* * *}\end{array}$ & $\begin{array}{l}0.113 \\
(0.029)^{* * *}\end{array}$ \\
\hline Physical capital $t-1$ & $\begin{array}{l}-0.087 \\
(0.020)^{* * *}\end{array}$ & $\begin{array}{l}-0.074 \\
(0.028)^{* * *}\end{array}$ & $\begin{array}{l}-0.049 \\
(0.010)^{* * *}\end{array}$ & $\begin{array}{l}-0.046 \\
(0.019)^{* *}\end{array}$ \\
\hline Ordinary labour & $\begin{array}{l}0.221 \\
(0.075)^{* * *}\end{array}$ & $\begin{array}{l}0.072 \\
(0.085)\end{array}$ & $\begin{array}{l}-0.113 \\
(0.056) * *\end{array}$ & $\begin{array}{l}-0.240 \\
(0.085)^{* * *}\end{array}$ \\
\hline Ordinary labour $_{\mathrm{t}-1}$ & $\begin{array}{l}-0.268 \\
(0.067)^{* * *}\end{array}$ & $\begin{array}{l}-0.233 \\
(0.090)^{* * *}\end{array}$ & $\begin{array}{l}-0.006 \\
(0.054)\end{array}$ & $\begin{array}{l}0.136 \\
(0.079)^{*}\end{array}$ \\
\hline UNI-NAT $^{1}$ & $\begin{array}{l}0.025 \\
(0.005)^{* * *}\end{array}$ & $\begin{array}{l}0.074 \\
(0.018)^{* * *}\end{array}$ & $\begin{array}{l}0.062 \\
(0.005)^{* * *}\end{array}$ & $\begin{array}{l}0.141 \\
(0.023)^{* * *}\end{array}$ \\
\hline Dom-MNE $^{1}$ & $\begin{array}{l}0.106 \\
(0.012)^{* * *}\end{array}$ & $\begin{array}{l}0.184 \\
(0.033)^{* * *}\end{array}$ & $\begin{array}{l}0.137 \\
(0.015)^{* * *}\end{array}$ & $\begin{array}{l}0.283 \\
(0.048)^{* * *}\end{array}$ \\
\hline For-MNE $^{1}$ & $\begin{array}{l}0.141 \\
(0.015)^{* * *}\end{array}$ & $\begin{array}{l}0.173 \\
(0.031)^{* * *}\end{array}$ & $\begin{array}{l}0.169 \\
(0.016)^{* * *}\end{array}$ & $\begin{array}{l}0.180 \\
(0.038)^{* * *}\end{array}$ \\
\hline Metro-Stlm² & $\begin{array}{l}0.097 \\
(0.016)^{* * *}\end{array}$ & $\begin{array}{l}0.088 \\
(0.024)^{* * *}\end{array}$ & $\begin{array}{l}0.039 \\
(0.009)^{* * *}\end{array}$ & $\begin{array}{l}0.045 \\
(0.024)^{*}\end{array}$ \\
\hline Metro-Gbg ${ }^{2}$ & $\begin{array}{l}0.044 \\
(0.012)^{* * *}\end{array}$ & $\begin{array}{l}0.086 \\
(0.027)^{* * *}\end{array}$ & $\begin{array}{l}0.031 \\
(0.008)^{* * *}\end{array}$ & $\begin{array}{l}0.044 \\
(0.025)^{*}\end{array}$ \\
\hline Metro-Malmö $^{2}$ & $\begin{array}{l}0.038 \\
(0.013)^{* * *}\end{array}$ & $\begin{array}{l}0.043 \\
(0.028)\end{array}$ & $\begin{array}{l}-0.008 \\
(0.010)\end{array}$ & $\begin{array}{l}0.037 \\
(0.027)\end{array}$ \\
\hline Observations & 55009 & 28625 & 85677 & 22327 \\
\hline Number of id & 10198 & 7451 & 17934 & 4711 \\
\hline
\end{tabular}

Notes:

Manufacturing (MAN), Knowledge intense business services (KIBS), Retail and Wholesale (RW), Transport and Rental (TR).

Standard errors within parentheses. * Significant at 10\%; ** significant at 5\%; *** significant at $1 \%$

Test statistics for serially correlated error and overidentifying restrictions are satisfactory.

Year dummies are included in the regressions 
Table D. Nearest neighbour matching between exporting and non-exporting firms. Dependent variable is labour productivity $(\log )$

\begin{tabular}{|l|llll|}
\hline \hline & MAN & KIBS & RW & TR \\
\hline Exports & 0.070 & 0.096 & 0.180 & -0.007 \\
& $(0.022)^{* * *}$ & $(0.027)^{* * *}$ & $(0.013)^{* * *}$ & $(0.044)$ \\
$\begin{array}{l}\text { Observations in the } \\
\text { matching process }\end{array}$ & 2,270 & 2,811 & 8,581 & 2,235 \\
\hline \hline
\end{tabular}

Notes:

Manufacturing (MAN), Knowledge intense business services (KIBS), Retail and Wholesale (RW), Transport and Rental (TR).

Matching estimator: Average Treatment effect

Weighting matrix: Inverse variance

Selection variable: The binary export indicator

Matching variables: sales/total assets ${ }_{\mathrm{t}-1}(\log )$, equity/total assets ${ }_{\mathrm{t}-1}(\log )$, total assets/ employee $(\log )$, firm size (log), human capital, corporate ownership structure, region and years.

Number of matches from firms in the non-exporting group per observation in the exporting group: 2

Exact matching variables: Regions and corporate ownership structure

Standard errors within parentheses. * Significant at $10 \%$; ** significant at 5\%; *** significant at $1 \%$ 